\title{
Graduation Approach - Economic Resilience for Extreme Poor - Ethnography Study from World Vision India's Intervention in Assam
}

\author{
Subramania Siva \\ Research Officer, \\ World Vision India, Chennai, India
}

\author{
Priskila Macwan \\ Technical Specialist-Resilience, \\ World Vision India, Calcutta, India
}

\begin{abstract}
This paper attempts to look at graduation model as a successful intervention to move communities out of poverty. In Assam Udalguri district the graduation model was implemented during August 2014 to September 2016 by world vision India- child focused humanitarian organization working in over 6200 communities in India. Graduation Model refers to move the vulnerable household from extreme poverty to next level to have food security, livelihood assets, and linkages with development programs within a period of 24 months. This study focused on vulnerable poor in the communities mainly Single mothers, Widows, Landless labor, poor household having chronically ill, poor household with person with disability, and household with malnourished household.300 participants selected through screening in this program, baseline survey data has been collected and at the end of the tenure we had end line survey with the same set of questionnaire to see the shift between two time points. 297 participants moved from extreme poverty to sustainable development consider once they attain $75 \%$ on 16 indicators mentioned below. This Ethnography study resulted in $99 \%$ success of program by comparing the baseline and end line data. The paper, therefore suggests that graduation model is a successful approach to assist vulnerable households to move out from extreme poverty.
\end{abstract}

KEYWORD: Graduation Model, Vulnerable Poor, Economic Assistance

\section{INTRODUCTION}

The Intervention area is in Udalguri block under Udalguri district spreads below Bhutan foot hills. The area was cut off by lack of transportation and proper road communication facilities. The economic condition of the communities was very low. People lived from hand to mouth. Less than $10 \%$ have $1-2$ big has of lands which are hardly cultivable due to scarcity of water. People were deprived of availing medical treatment due to both inaccessibility \& lack of health structure and poverty. Education and building leadership was absent. The term "graduation" refers to participants moving out of safety net programs and "graduating" into incomeearning activities that let them sustains themselves without external subsidies. Graduation approach targeted extreme poor households which incorporate Women empowerment to increase control over household economic resources and greater power in decision making. The graduation approach brings together several components that have proven necessary for sustained upwards economic mobility, social protection \& financial inclusion for the poorest and most vulnerable.

\section{Components of Graduation Approach:}

\section{Specific Targeting}

Based on developed targeting criteria reaching out to vulnerable-poor household through the process of PRA and door to door survey.

\section{Safety Net}

Through Consumption Support, beneficiaries are encouraged to focus on their new business while consumption stipend of Rs. 20 a day for 45 to 90 days, depending on the particular enterprise selected by the households, takes care of their daily basic requirement. As per World Vision India guideline, the support was given in kind and to control the use of stipend for right purpose, beneficiaries were liked with Grocery shops (eg. Rice, oil, sugar etc) or petty business (eg. Selling fodder, Livestock medicine) taken by beneficiary under this program. So in order both are benefited and motivated. And are also linked to Government welfare assistance and many other learning as per requirement and context like saving a day fistful of rice 


\section{Savings}

At initial stage of program beneficiaries are motivated to get into saving habit by informal savings in piggy bank a minimum of Rs.10 a day, and once they are assisted with asset are linked to formal savings by opening account and depositing regular amount minimum Rs, 100 a month.

\section{Skill Training}

The Technical Skills Training starts with Counselling individual beneficiary and the family members to have positive thinking and effectively participate in program. Then beneficiaries are taken through confidence building and enterprise development training where they understand poverty cycle, society in which they live, graduation approach and its process bringing impact in once life, knowing business requirement and finally select business as per one interest and capacity.

Soon after business selection in a week time beneficiaries are given specific training on chosen enterprise after which within 30 days asset is transfer. Once the asset is in hand over to beneficiaries within time period of 15 to 30 days 1 st referral is given to identify any issue with ongoing business, which strengthen beneficiary failing or falling back. Later every quarter the refresher training continues.

Finally, the Life Skills Coaching also starts soon after transferring asset by doing weekly home visit and group visit, where they are given awareness on social, health \& hygiene issues, financial literacy, writing numbers and singing name, and also following day to day business transaction and family wellbeing. Regular coaching and mentoring actually builds beneficiary confidence level higher and higher day by day to actively and effectively perform well as guided under program.

Basically the technical training and life skill coaching was given to motivate and empowered beneficiaries not only what they have chosen business and learned skills now, but in future also they follow the same in doing any business and get success.
5. Support for productive asset (Market Analysis and Asset Transfer) Based on market study enterprise list was prepared and shared with beneficiaries who chosen income-generating activity which got ultimate market for the goods and services. The productive asset support was given in 2 to 3 phases and was encouraged to choose different business each time, so they are not affected much by doing little progress in one particular business, at the same time it gives them different coping mechanism to depend on. The first phase was supported with maximum Rs.5,000, as most of the beneficiary being first generation to do business, need to give them time to learn and have confidence, also this gives space to beneficiary to change the income generating activity if any major challenge. At the same time program like this having very fix time line and budget also reduce the risk of investing whole asset money once and left with no further support to beneficiary. Prior to transferring productive primary asset beneficiary were supported to make sure available supportive assistance eg. For Business on Readymade garments - Garments become primary asset whereas trunk to keep safe garments, bag to carry garment for sale become supportive asset.

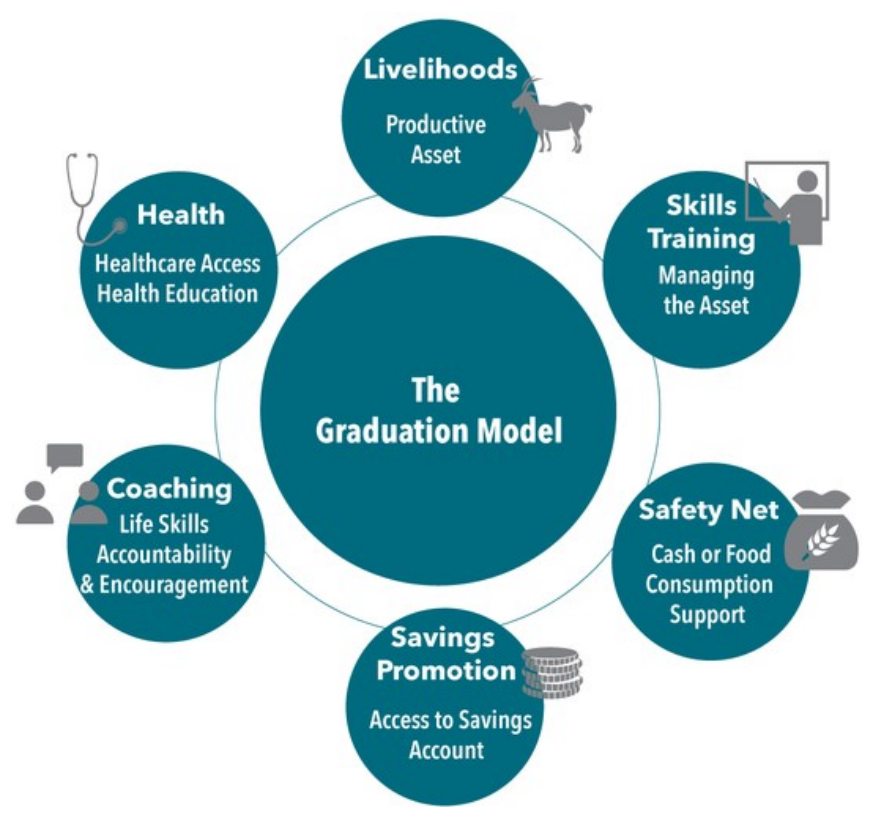


International Journal of Trend in Scientific Research and Development, Volume 1(4), ISSN: 2456-6470 www.ijtsrd.com

\begin{tabular}{|c|c|c|c|}
\hline onths & d Six months & Six months & ths \\
\hline $\begin{array}{l}\text { - Deployment of field } \\
\text { staff and building } \\
\text { their capacity } \\
\text { - Area level } \\
\text { information } \\
\text { collection } \\
\text { - Beneficiary selection } \\
\text { - Baseline Assessment } \\
\text { - Counselling, } \\
\text { confidence building } \\
\text { training \& selection } \\
\text { of enterprise } \\
\text { - Enterprise } \\
\text { development training } \\
\text { - Formation } \\
\text { committee of } \\
\text { - Asset transfer (In } \\
\text { kind) } \\
\text { - Monthly meeting of } \\
\text { committee } \\
\text { Handholding support } \\
\text { at household level } \\
\text { - }\end{array}$ & $\begin{array}{l}\text { - Asset transfer (In } \\
\text { kind) } \\
\text { - Handholding support } \\
\text { at household level } \\
\text { and in group (Social, } \\
\text { Livelihood \& } \\
\text { Financial aspect) } \\
\text { - Monthly meeting of } \\
\text { committee } \\
\text { - Quarterly Refresher } \\
\text { training }\end{array}$ & $\begin{array}{l}\text { - Handholding support } \\
\text { at household level } \\
\text { and in group (Social, } \\
\text { Livelihood \& } \\
\text { Financial aspect) } \\
\text { - Monthly meeting of } \\
\text { committee } \\
\text { - Quarterly Refresher } \\
\text { training }\end{array}$ & $\begin{array}{l}\text { - Handholding support } \\
\text { at household level } \\
\text { and in group (Social, } \\
\text { Livelihood \& } \\
\text { Financial aspect) } \\
\text { - Monthly meeting of } \\
\text { committee } \\
\text { - Quarterly Refresher } \\
\text { training } \\
\text { - Graduation training } \\
\text { for field staff } \\
\text { - Graduation Training } \\
\text { for beneficiaries } \\
\text { - End line assessment } \\
\text { - Phase out with } \\
\text { Graduation ceremony }\end{array}$ \\
\hline
\end{tabular}

Table 1: 24 months breakups of graduation appraoch

\section{LITERATURE REVIEW:}

Since 2002, BRAC's challenging the Frontiers of Poverty Reduction (CFPR)/Targeting the Ultra Poor Program (TUP) had supported over half a million very poor households to increase their income and assets in a sustained fashion in Bangladesh. Households not only earned and saved more but also diversified their assets and income sources: the value of productive assets tripled (Bandiera et al. 2016). Impacts were observed to be even larger seven years after the asset transfer, and five years after the end of the program (the change in spending on nondurables was 2.5 times higher after seven years than after four, and the increase in land access doubled).

Graduation programs have statistically significant impact on consumption, participants productive assets and savings habit. Impact assessments also show that participants spent more time working, went hungry on fewer days, experienced lower levels of stress, and reported improved physical health. New results from one of the CGAP-Ford Foundation sites in India almost six years after the end of the program revealed even greater impact, with a doubling in per capita 


\section{www.ijtsrd.com}

consumption compared with the three-year mark (The Economist 2015). Additional research in Ghana compared the transfer of assets alone (goats) to the receipt of the full package of graduation components; after three years, the value of the assets held by households that received the full package was significantly higher and more diversified than for the goats-only households whose livestock value and total consumption did not increase.

The total per household cost of the programs (including consumption assistance, seed capital, training, mentoring, staffing, monitoring, and office overhead), over the entire duration of the programs, ranged from US\$330 to US\$700 in Bangladesh, India, Yemen, Ethiopia, and Pakistan. The cost-effectiveness of the program is high, with annual household income gains as a percentage of total program costs ranging from about 7 percent to 25 percent in the five sites where the program had positive impact. At BRAC, the initial investment of US\$365 was estimated to yield total benefits of US\$1,168 over a projected span of 20 years (the discounted sum of consumption and asset gains in 2007 U.S. dollars).

\section{Methods:}

The Graduation Model initiated with identifying Village Council Development Committee (VCDC) and villages based on primary, secondary information where 52 PRAs (Participatory Rural Appraisal) conducted covering 56 villages and 3805 Household to deliberately target poorest 300 participants were identified as extreme poor and finally selected for Graduation Model. As per baseline, target HHs were food insecure, low income, wage labor, lack of own property / asset, no land, not protected by safety net, absent from financial inclusion and absent of WASH component, those relevant participants information was collected through census survey as termed as Baseline data. At the end of the tenure we did the end line survey with the same set of questionnaire to see the shift between two time points.

World vision conducts Participatory Rural Appraisals (PRAs) in selected villages from to identify the subset of the population most likely to be Ultra Poor. The PRA consists of a social mapping and a wealth ranking. Following identification, all the participants are selected to receive assets. WV took few steps before asset distribution as follows: counseling and confidence building training conducted to enhance the capacity, Enterprise development training done along with business plan. WV staff meets with participants to select the livelihood option best suited to the household. WV purchases and distributes assets such as livestock and inventory to participants. The grants are also used to finance other inputs, such as fodder and sheds for livestock. After transferring asset participant is regularly motivated with weekly house visit and refresher trainings. In this sample, $90 \%$ of participants chose livestock, receiving either 2 cows, 4 goats or 1 cow and 2 goats. The value of the asset transferred was approximately US\$150, or Rs.10000/which is around $20 \%$ of baseline annual household expenditure. Over the next 18 months, WV staff meets weekly with participants. These meeting are primarily held to provide information and training on topics related to the household's enterprise (such as proper care for livestock) as well broader social and health issues. Additionally, participants were encouraged to save Rs.10 (approximately \$US 0.25) per week at these meetings. To support participant needs in terms of consumption, stipend Rs.20/- was given as allowance provided for 12 weeks. Approximately 18 months after receipt of the asset, the participants are "'graduated" to sustainable livelihood by achieving $75 \%$ of indicators. As most of the Ultra Poor households do not have prior experience with formal financial institutions like Post office or MFIs, WV conducted a three-day Refresher course for program participants to address Loan repayment, number of social, health and community issues and explains the functioning of a Graduation approach, its rules and regulations, group solidarity and the role of savings in one's financial life.

\section{THE ETHNOGRAPHIC RESEARCH}

While the empirical surveys provide quantitative data on the improvements in economic, Social and health conditions of participants, we conducted a year-long ethnographic research to better understand their lives, the process through which these changes took place and the factors that held them back. The study analyzed how Extreme poor households build resilience, improve their conditions and graduate out of extreme poverty, as well as understand the dynamics that prevent many of them from moving up. Tools included: 
- Observations

- Community wealth ranking

- In-depth interviews

- Conversations with participants and key informants

- Life-histories of beneficiaries

\section{RESULTS}

- $82.66 \%$ Participants have access to Sanitary Latrine which will impact of health management

- Number of income source also increased which will results in spending for children's education.

- $67.66 \%$ of the participants are practicing family planning.

- $92.33 \%$ of the participants are having voter card

\begin{tabular}{|c|c|c|c|}
\hline & Key Indicators & Baseline & 1 Year MIS \\
\hline 1 & At least two Income sources in the family & 109 & $297 \mathrm{HH}$ \\
\hline 2 & Income of family will be increased significantly & $\begin{array}{c}\text { All } 300 \\
\text { HH Below } \\
1600 \text { per } \\
\text { month }\end{array}$ & $\begin{array}{l}297 \text { - Increased to above } \\
1600 \text { to } 3000 \text { per month }\end{array}$ \\
\hline 3 & Growing Saving Habits and deposits & 0 & $\begin{array}{l}293 \text { - Link to post office \& } \\
\text { Bank }\end{array}$ \\
\hline 4 & $\begin{array}{l}\text { All members of the family are getting at least two full-meals } \\
\text { every day }\end{array}$ & 0 & 300 \\
\hline 5 & $\begin{array}{l}\text { Participant planted at least two fruit plants or cultivates two } \\
\text { types of vegetables in own garden }\end{array}$ & 0 & 300 \\
\hline 6 & All children of below 5 years of the family are immunized & $62 / 74$ & $\begin{array}{l}12 \text { - under Immunization } \\
\text { process }\end{array}$ \\
\hline 7 & $\begin{array}{l}\text { All school going aged children are admitted and continuing in } \\
\text { school }\end{array}$ & $95 / 168$ & $\begin{array}{l}73 \text { - Admitted to school and } \\
\text { are regularly attending }\end{array}$ \\
\hline 8 & $\begin{array}{l}\text { Eligible couple in the family practicing family-planning } \\
\text { method }\end{array}$ & 28 & 212 \\
\hline 9 & Residential house of the family is safe & 13 & 287 \\
\hline 10 & Household has access to basic medical services and facilities & 0 & 300 \\
\hline 11 & Participant can write their names and numbers (1-10) properly & 21 & 279 \\
\hline 12 & Participant has voter identity card & 85 & 192 \\
\hline 13 & Participant has ration card & 6 & 277 \\
\hline 14 & $\begin{array}{l}\text { All members of the family wear clean clothes and they are } \\
\text { maintaining cleanliness in their house }\end{array}$ & 0 & $\begin{array}{l}300 \mathrm{HH} \text { - Behavioral change } \\
\text { is evident }\end{array}$ \\
\hline
\end{tabular}

- The Graduation approach increased ultra-poor households' consumption, a common measure of well-being.

- Consistent with increasing food expenditure, household members were able to afford two meals per day more often.

- 97.33 Participants Savings habit range from 2000 to 7000 increased significantly and persistently, and gains were largest in countries with mandatory savings.

- $94.33 \%$ of the participants are having ration card

- $99.66 \%$ of the participants are having job cards 


\begin{tabular}{|l|l|l|l|}
\hline 15 & Household has proper access to safe drinking water & 0 & 300 \\
\hline 16 & Family members are using safe \& hygienic latrines & 0 & 248 \\
\hline
\end{tabular}

Overall Result of the program - 99\%

Measuring Categories of participants apart from noneconomic indicators as given below out of 300 participants' 297 participants graduated which is evident. There was 3\% failure was observed ${ }^{1}$

\section{CONCLUSION}

The Graduation approach focused most vulnerable households to move out of extreme poverty through sustainable livelihoods and increase income. This approach is process oriented with rigor on the steps to be carried out along with time ( 24 months). The graduation program combines support for immediate needs with longer term investments in training, financial services, and business development so that within two years vulnerable-poor equipped to help themselves move out of extreme poverty.

The Graduation Approach is not a short-term escape from extreme poverty but instead seeks to equip participants with self-confidence to sustain them after end of the Program.

The Graduation approach should form an integral component of national social protection to eradicating extreme poverty by 2030 suggested by SDG's.

\section{Recommendations for future study}

\section{Which components of the Graduation approach drive results?}

While many anti-poverty solutions aim to improve livelihood through provision of assets, temporary financial support, mandatory savings or skill trainings, none have been packaged and applied these approaches together in a way which is both cost effective and has demonstrated clear impact on the lives of the ultra-poor and are often bypassed under scale of poverty alleviation initiatives.

\footnotetext{
${ }^{2}$ As per the program requirement 3 participants could not meet the criteria, as the sad demise of two participants took place and in one family due to their internal fight wife kept on moving for her survival, she could not attain programs and available during visit and could not maintain assets
}

Does Graduation approach affect others in the community and nearby communities?

As this study impacted the lives of vulnerable poor and need more study on impacts of approach to nearby communities.

\section{Does Graduation approach sustain over a longer time horizon?}

Evidence on longer-term impacts will provide more practical suggestions on comparative cost-benefit analyses of Graduation and alternative approaches that target the vulnerable-poor.

\section{REFERENCES}

1. Bandiera, Oriana, Robin Burgess, Narayan Das, Selim Gulesci, Imran Rasul, and Munshi Sulaiman. "Can Basic Entrepreneurship Transform the Economic Lives of the Poor?" London School of Economics Economic Organisation and Public Policy Discussion Papers EOPP 043, April 2013.

2. Banerjee, Abhijit, Esther Duflo, Nathanael Goldberg, Dean Karlan, Robert Osei, William Parienté, Jeremy Shapiro, Bram Thuysbaert, and Christopher Udry. 2015. "A Multi-faceted Program Causes Lasting Progress for the Very Poor: Evidence from Six Countries." Science 348 (6236):

1260799-1-1260799-16. doi:10.1126/science.1260799.

3. Banerjee, Abhijit, Esther Duflo, Raghabendra Chattopadhyay, and Jeremy Shapiro. "Targeting the Hard-Core Poor: An Impact Assessment." Center for Microfinance Working Paper, November

2011.

4. Banerjee, Abhijit, Esther Duflo, Raghabendra Chattopadhyay, and Jeremy Shapiro. "Targeting Efficiency: How well can we identify the poor?" Center for Microfinance Working Paper Series No. 21, December 2007.

5. Banerjee, Abhijit V., and Esther Duflo. 2007. "The Economic Lives of the Poor." Journal of 
Economic Perspectives 21 (1): 141-168. Poverty and Transform Economies through

6. Blattman, Christopher, Eric Green, Julian Jamison, Christian Lehmann, and Jeannie Annan. Forthcoming. "The returns to microenterprise support among the ultra-poor: A field experiment in post-war Uganda." American Economic Journal: $\quad$ Applied $\quad$ Economics

7. Blattman, Christopher, Nathan Fiala, and Sebastian Martinez. 2014. "Generating Skilled Self-Employment in Developing Countries: Evidence from Uganda." Quarterly Journal of $\begin{array}{llll}\text { Economics } & 129 & \text { (2): } & 697-752 .\end{array}$

8. Haushofer, Johannes, and Jeremy Shapiro. "Household Response to Income Changes: Evidence from an Unconditional Cash Transfer Program in Kenya." Working Paper, 2013. http://www.princeton.edu/ joha/publications/ Haushofer_Shapiro_UCT_2013.pdf.

9. Karlan, Dean and Bram Thuysbaert. "Targeting Ultra-Poor Households in Honduras and Peru." NBER Working Paper No. 19646, November 2013. doi:10.3386/w19646.

10. United Nations High Level Panel of Eminent Persons on the Post-2015 Development Agenda. 2013. A New Global Partnership: Eradicate
Sustainable Development. New York: United Nations

Publications.

11. World Bank. 2013. The World Bank Annual Report 2013. Washington, DC: World Bank. doi:10.1596/978-0-8213-9937-8.

12. Bandiera, Oriana, Robin Burgess, Narayan Das, Selim Gulesci, Imran Rasul, and Munshi Sulaiman. 2016. "Labor Markets and Poverty in Village Economies." Quarterly Journal of Economics.

13. http://www.cgap.org/web-publication/graduationpathways-increasing-income-and-resilienceextreme-poor

14. http://www.cgap.org/publications/creatingpathways-poorest

15. Sulaiman, Munshi, Nathanael Goldberg, Dean Karlan, and Aude de Montesquiou. 2016. "Eliminating Extreme Poverty: Comparing the Cost Effectiveness of Livelihood, Cash Transfer, and Graduation Approaches." Forum. Washington, D.C.:

16. http://www.poverty-action.org/impact/ultra-poorgraduation-model 